
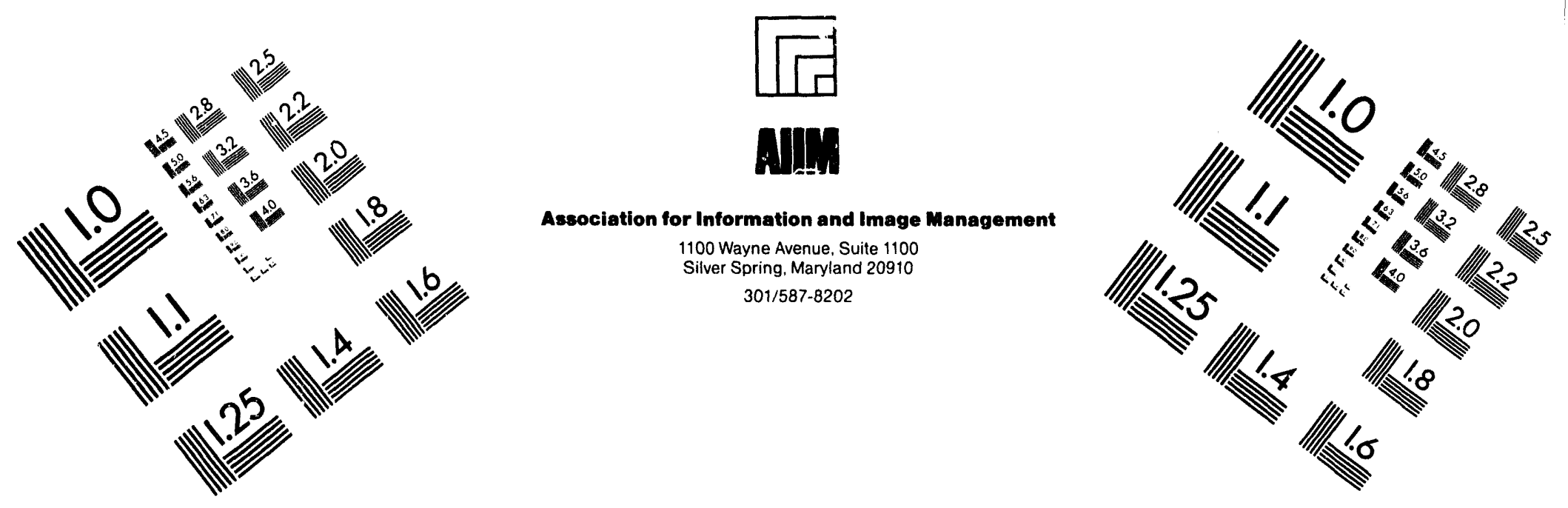

\title{
Centimeter
}

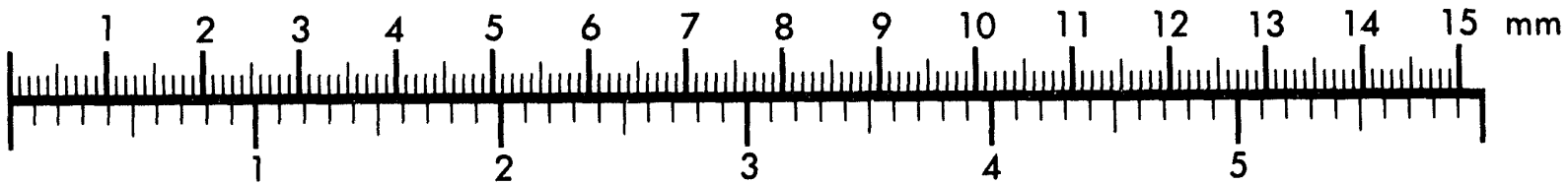
Inches
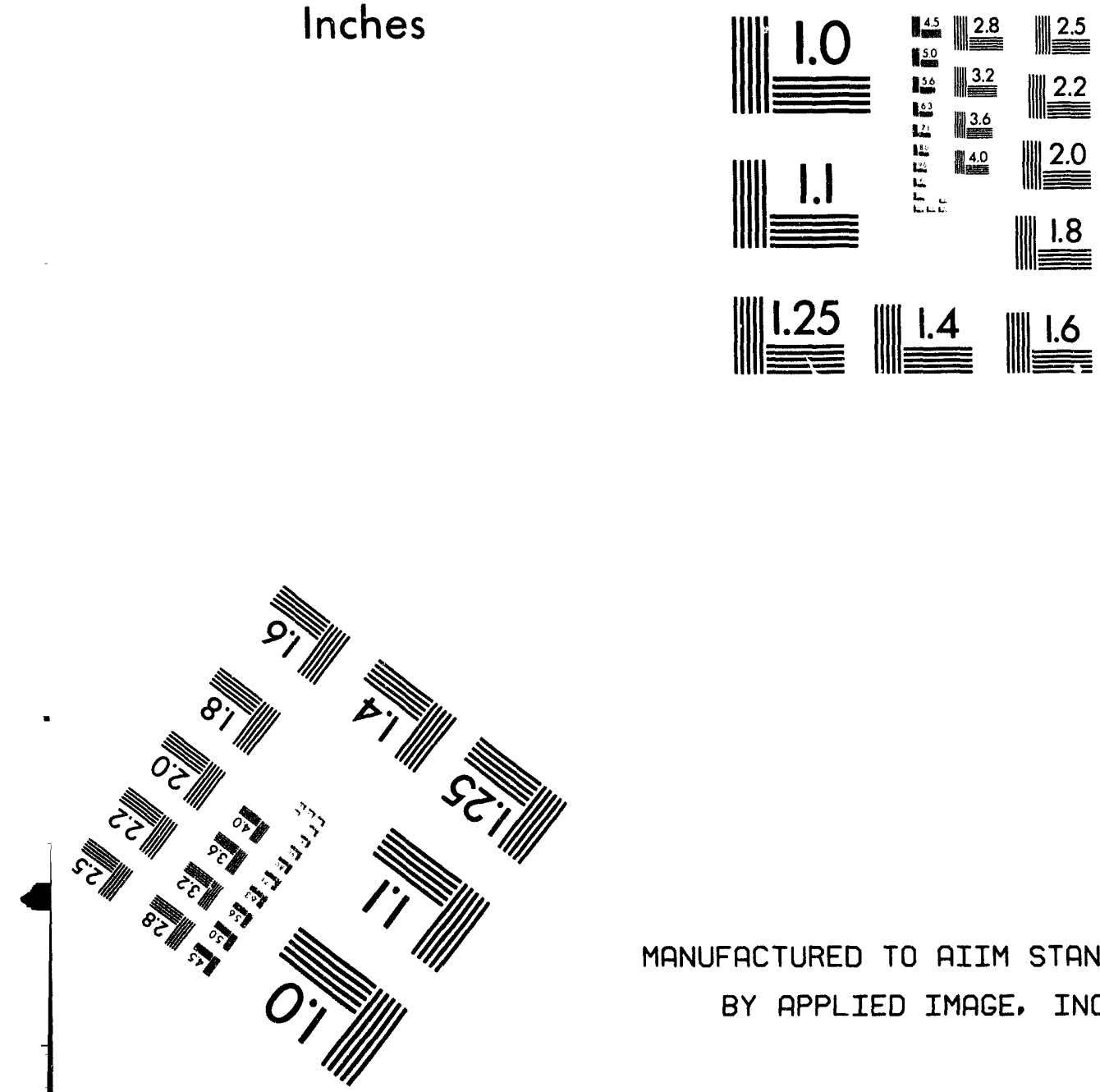

MANUFACTURED TO AIIM STANDARDS BY APPLIED IMAGE, INC.

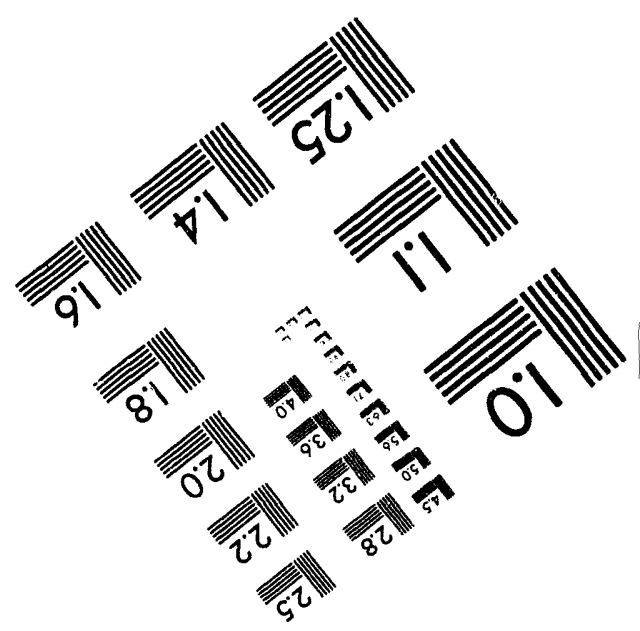



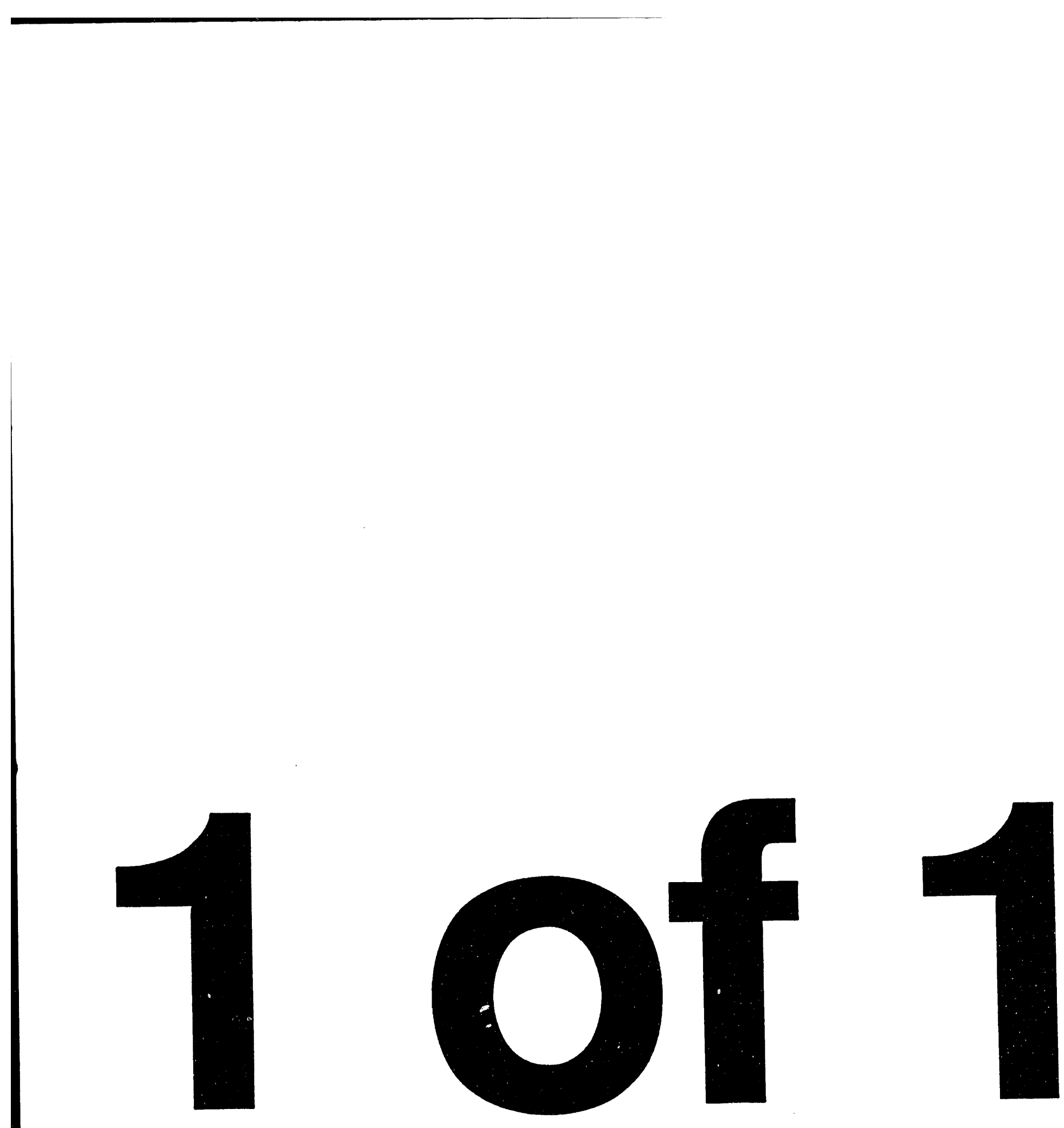

1 


\section{MIDDLE AND UPPER CRETACEOUS AMBER FROM THE TAIMYR PENINSULA, SIBERIA - EVIDENCE FOR A NEW STRUCTURAL SUB-CLASS OF RESINITE.}

Sir,

Analysis of three amber (resinite) samples collected from Middle and Upper Cretaceous sediments in the Taimyr Peninsula, Siberia, indicates that these materials are based on copolymers of biformene (I) and communol (II). No resinites of similar structural character have previously been described and hence, these samples represent a previously unknown structural sub-class of resinite.

Recently, the chemical structures of resinites have received considerable attention ${ }^{1-5}$ due primarily to their potential value as geochemical indicators of sedimentary environments. As a consequence of this work, a classification system which differentiates five structurally distinct classes of resinites has been proposed ${ }^{1,2}$. The most common form of resinites in the geosphere, Class I resinites, are those based primarily on polymers of the labdanoid carboxylic acids communic acid (III) and ozic acid (IV) . (Structural characteristics of polymers of these acids have been described elsewhere ${ }^{1,3,4,6}$ ) Class I resinites are (currently) further divided into three sub-classes to differentiate between resinites based primarily on polymers of communic acid (Class Ia and Ib) and those based primarily on polymers of ozic acid (Class Ic) ${ }^{1}$. Resinites based on polymers of other labdanoids have not previously been described although analogous polymers of other labdanoids are known in modern samples?.

In the present study three resinites, collected independently from two sites in the central and northern regions of the Taimyr Peninsula, Siberia, (Baiku-Neru (Taimyr Lake), and Yantardakh Hill (two samples)), have been analyzed to determine details of their chemical structures. The samples were collected from Upper Cretaceous (Upper Coniacian-Lower Santonian) (Yantardakh Hill) and Middle Cretaceous (Albian-Cenomanian) (Baiku-Neru)

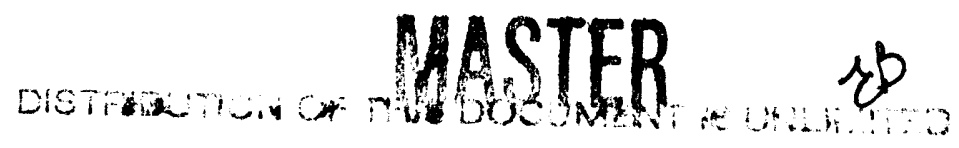


sediments, which places these samples among the oldest ambers so far subjected to detailed structural analysis.

Pyrolysis-gas chromatographic-mass spectrometric (Py-GC-MS) analysis is arguably the most useful technique for detailed analysis of the organic structural characteristics of resinites ${ }^{3}$. PyGC-MS analysis of these resinites indicates that they are based on copolymers of biformene (I) and communol (II). A total ion chromatogram obtained by Py-GC-MS analysis of one of these samples, (Yantardakh Hill) is illustrated in Figure 1. Analysis of the remaining samples gave data comparable to that illustrated in Figure 1. Assigned structures of the principal components of the pyrolysate (those numbered in enlarged bold type in Figure 1) are illustrated in Scheme I. (Additional details of the analyses of all three Taimyr resinite samples, including assignments for minor components and the basis for the structural assignments given in Scheme I will be described elsewhere.)

The structural characteristics of the principle components of pyrolysate, particularly compounds $11,12,18,19,21,22,24$, and 25 , are analogous to the bicyclic acids (V-VIII) which have been shown to be characteristic of Class Ia and Ib resinites ${ }^{1,3,4}$. Hence, it is possible to infer details of the structural characteristics of the polymeric back-bone of the resinite structure from these data. Compounds $11,12,18$ and 19 are clearly derived from the A/B ring system of biformene (I) monomers within the polymeric resinite structure. Similarly, compounds $21,22,24$, and 25 are derived from communol (II) monomers. The absence of compounds V-VIII indicates that communic acid monomers are not present in the structure of this sample, which clearly differentiates this material from previously described polylabdanoid resinites. Compounds $27-30$ are occluded diterpenoids which are not part of the polymeric structure.

Based on these observations it is apparent that this sample (and two similar ambers from the same region) represent the first reported examples of biformene/communol copolymeric resinites. Therefore, in order to differentiate these materials from other polylabdanoid resinites, it is necessary to define a new resinite structural sub-class: (viz; Class Id) to delineate polylabdanoid resinites based on polymers communol and/ or biformene, (in which 
communic acids are absent), from other Class I resinites.

Ken B. Anderson

Chemistry Division

Argonne National Laboratory

Argonne, IL, 60439. USA and

Amoco Oil Company.*

PO Box 3011

Naperville, IL, 60566-7011. USA

\section{* Present Address}

\section{Acknowledgements.}

The author wishes to express his appreciation to Dr R.Gangloff of the University Museum, Fairbanks, Alaska; and Prof. B. Saunders, Bryn Mwyr College, Pennsylvania for generously donating the amber samples discussed above. Support of the US DOE under contract No W31-109-ENG-38 for a part of this work is also acknowledged. Amoco Oil Company and Amoco Corporation are thanked for permission to publish.

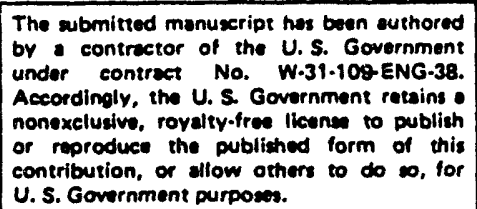


References.

1. Anderson K.B., Winans R.E., Botto R.E. Org. Geochem. 18(6), 829-841 (1992).

2. Anderson K.B. and Botto R.E. Org. Geochem. (In Press) (1993).

3. Anderson K.B. and Winans R.E. Anal. Chem. 63, 2901-2908 (1991) .

4. Van Aarssen B.K.G. (1992) Structural assignment and catagenetic behaviour of macromolecular constituents of recent and fossil natural resins. $\mathrm{PhD}$ Thesis, Technische Universiteit Delft., pp 167.

5. Crelling J.C., Pugmire R.J., Meuzelaar H.L.C., McClennen W.H., Huai H., Karas J. Energy and Fuels 5, 688-694 (1991).

6. Carman R.M., Cowley D.E., Marty R.A. Aust. J. Chem. 23, 1655-1665 (1970).

7. Carman R.M. and Dennis N. Aust. J. Chem. 20, 157-162 (1967) 


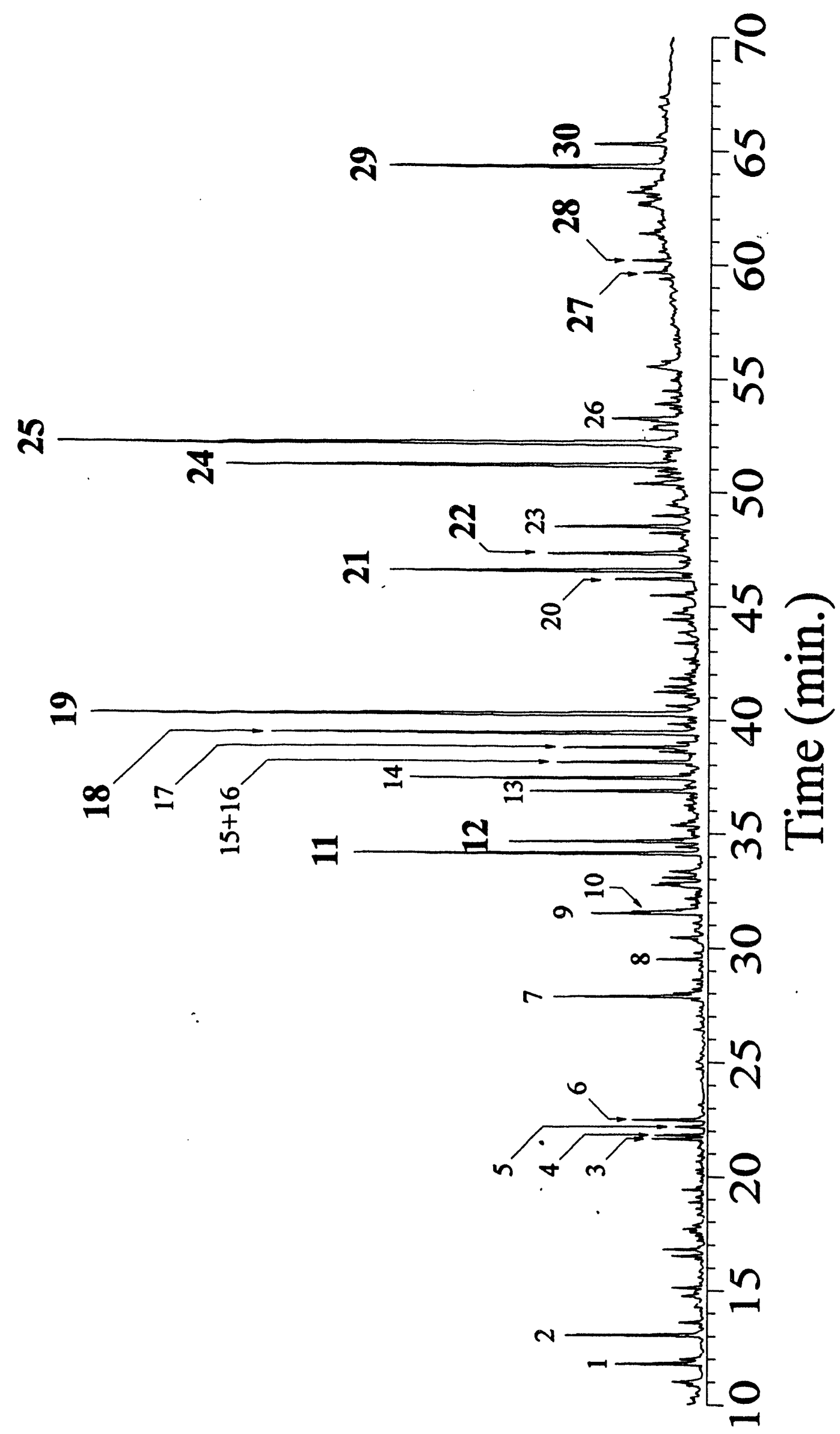


<smiles>[R][C@]1(C)CCC[C@]2(C)[C@H]3CCC4=CC(C=C)=CC[C@@H]4[C@H]3CC[C@]12C</smiles>

I : $\mathrm{R}=\mathrm{CH}_{3}$

II $: \mathrm{R}=\mathrm{CH}_{2} \mathrm{OH}$

III : $\mathrm{R}=\mathrm{CO}_{2} \mathrm{H}$

(trans isomer shown)<smiles>C=CC1=CC[C@H]2C(=C1)CCC1[C@@](C)(C(=O)O)CCC[C@@]12C</smiles>

IV

(trans isomer shown)<smiles>CC1=C[C@]2(C)CCC[C@](C)(C(=O)O)C2CC1</smiles>

V

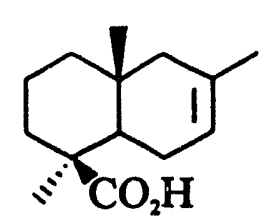

VI<smiles>CC1=C(C)[C@]2(C)CCC[C@](C)(C(=O)O)C2CC1</smiles>

VII<smiles>C=C1C(C)=CCC2CCC[C@](C)(C(=O)O)C12</smiles>

VIII
$\underbrace{11}_{\mathrm{CO}_{2} \mathrm{H}} \begin{aligned} & 12: \mathrm{R}=\mathrm{CH}_{3} \\ & \mathrm{R}=\mathrm{CH}_{2} \mathrm{OH}\end{aligned}$<smiles>CC1=C(C)[C@@]2(C)CCC[C@](C)(C(=O)O)C2CC1</smiles>

$18: \mathrm{R}=\mathrm{CH}_{3}$ $24: \mathrm{R}=\mathrm{CH}_{2} \mathrm{OH}$<smiles>CC(C)c1cccc(CC[C@H]2[C@H](C)CCC[C@]2(C)C(=O)O)c1</smiles><smiles>CC(C)c1ccc2c(c1)CCC1[C@@](C)(C(=O)O)CCC[C@@]21C</smiles>
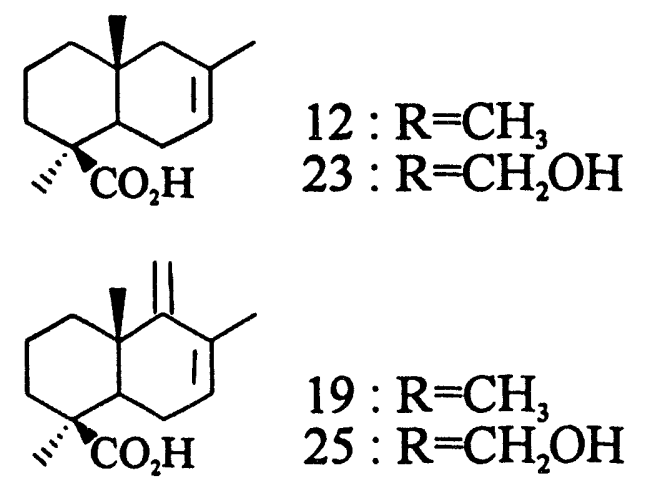<smiles>CC(C)c1cccc(CC[C@H]2[C@@H](C)CCC[C@]2(C)C(=O)O)c1</smiles><smiles>CC(C)C1=CC2=CCC3[C@](C)(C(=O)O)CCC[C@]3(C)C2CC1</smiles> 

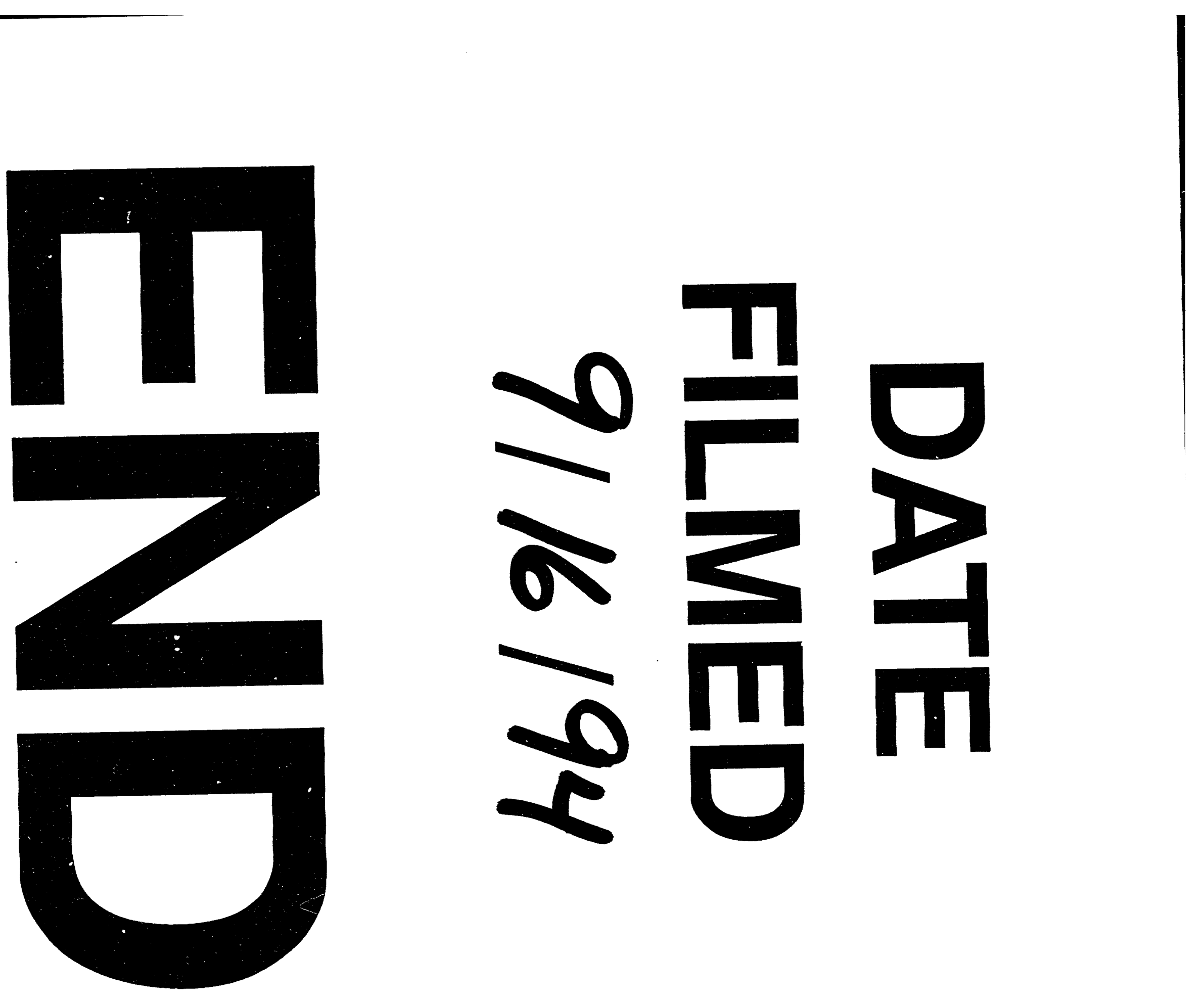


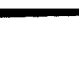

- 